\title{
Chemical Ecology of Astigmatid Mites LXVII. Neral [3,7-dimethyl-(Z)-2,6-octadienal]: The Female Sex Pheromone of an Acarid mite, Histiogaster sp. (Acari: Acaridae)
}

\author{
Hiroyuki HIRAOKA, Naoki MORI, Kimiko OKABE ${ }^{1}$, Ritsuo NISHIDA and Yasumasa \\ KUWAHARA* \\ Laboratory of Chemical Ecology, Division of Applied Life Sciences, Graduate School of \\ Agriculture, Kyoto University, Sakyo-ku, Kyoto 606-8502, Japan \\ ${ }^{1}$ Insect Ecology Laboratory, Forestry and Forest Products Research Institute, P.O. Box 16, \\ Norin Kenkyu-danchi, Tsukuba, Ibaraki 305-8687, Japan
}

(Received 4 April 2002; Accepted 23 April 2002)

\begin{abstract}
Neral [3,7-dimethyl-(Z)-2,6-octadienal] was identified to be the female sex pheromone of the mite Histiogaster sp. (Acari: Acaridae). The species originated from a fungal Trichoderma harzianum culture in Japan. The compound aroused males to mount females. Although the compound was detected in both sexes $(29.4 \pm 8.9 \mathrm{ng}$ in females and $5.7 \pm 1.9 \mathrm{ng}$ in males), the behavior observation suggested that males could distinguish females from males. Synthetic neral indicated the activity at $0.1-1 \mathrm{ng}$ doses. On the other hand, geranial [3,7-dimethyl- $(E)-2,6-$ octadienal, the geometrical isomer of neral at the 2-C position], did not sexually stimulate males. Males could, therefore, discriminate between neral and geranial. Escaping behavior was observed upon exposure of neral at $100 \mathrm{ng}$ and of geranial at $10-100 \mathrm{ng}$ doses.
\end{abstract}

Key words: Astigmatid mite, Histiogaster sp., female sex pheromone, neral, 3,7-dimethyl-(Z)-2,6-octadienal

\section{INTRODUCTION}

Eight species of Astigmata are known to possess sex pheromones. These mites can be classified into two groups. Acarus siro (Levinson et al., 1989) and A. immobilis (Sato et al., 1993 ) belong to a group in which two sex pheromones, produced by each sex, are involved in their courtship rituals. The other group consists of species each possessing only the female sex pheromone, Sancassania (=Caloglyphus) polyphyllae (Leal et al., 1989a), Aleuroglyphus ovatus (Kuwahara et al., 1992), S. rodriguezi (Mori et al., 1995), Sancassania sp. (tentatively named as Sancassania sp. MJ) (Mori et al., 1996), another Sancassania sp. (tentatively named as Sancassania sp. HP) (Mori et al., 1998), and Cosmoglyphus hughesi (Ryono et al., 2001). Although these female sex pheromones arouse male's mounting behavior, males also contain more or less of these compounds. Their ratios between sexes (female/male) differ by species, and these ratios appears to be a key factor to differentiate whether males of a species can discriminate females from males or not (Mori and Kuwahara, 2000; Ryono et al., 2001). Males selectively mount their females in the following cases: Sancassania sp. HP (ratio of female/male, 8.4/1), S. rodriguezi (6.3/1) and

* To whom correspondence should be addressed at: Fax: +81-75-753-6312; E-mail: kuwa34@kais.kyoto-u.ac.jp 
S. polyphyllae (3.4/1), while males cannot discriminate in the following cases: Sancassania sp. MJ (1.4/1) and C. hughesi (2.1/1).

As a part of the pheromone study on astigmatid mites, we examined the sex pheromone of Histiogaster sp., one of fungivorous species. The genus contains a number of species associated with subcortical habitats and fungal fruiting bodies. Several Histiogaster spp. are found in North America from elms and pine trees associated with weevils, bark beetles and long-horned beetles, and some of these mites use beetles for dispersal at the stage of deutonymphs and maybe eat either nematodes, fungi or the beetles (the eggs, larvae and pupa of them) (Jacot, 1936; Nesbitt, 1945; Griffiths, 1963; Davis and Hunter, 1963; Woodring, 1963, 1966; Hajek and Dahlsten, 1985; Kinn, 1987). The mite Histiogaster sp. used in this study originated from a fungal Trichoderma harzianum culture on July 1990 in Oita Prefecture (Japan). It is the first description of this genus in Japan (Okabe, 1993a). The species indicated an exponential population growth in feeding on several fungi except shiitake mushroom Lentinula edodes, and was suspected as possibly becoming a serious pest or an important pathogen vector for mushroom production (Okabe, 1993a, 1993b, 1994, 1996, 1999).

In the present paper, we identified the female sex pheromone of Histiogaster sp. The compound triggered mounting behavior of males. Based on its content difference between sexes, the male's ability to discriminate females from males was also discussed.

\section{MATERIALS AND METHODS}

Mites. A colony of the mite Histiogaster sp. (Acari: Acaridae) was maintained in a Petri dish $(90 \mathrm{~mm}$ in diameter $\times 20 \mathrm{~mm}$ in height) by feeding dried yeast at room temperature under humid conditions in our laboratory. The container was kept in a zip-lock plastic bag $(240 \times 170 \times 0.04 \mathrm{~mm})$ to maintain moisture level. Both sexes were randomly collected from the stock culture by a needle, and used without prior knowledge of their mating experiences. This strain was collected from a laboratory culture of the fungus Trichoderma harzianum, July 1990, in Oita Prefecture, Japan (Okabe, 1993a). Trichoderma harzianum is a serious economic pathogen for mushroom production.

Instrumental analyses. Gas chromatographic (GC) analysis was performed with a Hewlett Packard 6850 gas chromatograph with a flame ionization detector, using an HP-5 capillary column $(0.25 \mathrm{~mm} \times 30 \mathrm{~m}, 0.25 \mu \mathrm{m}$ in film thickness, Hewlett Packard $)$ with helium as the carrier gas at $1.23 \mathrm{ml} / \mathrm{min}$ in the split-less mode at a temperature programmed from $60^{\circ} \mathrm{C}$ for $2 \mathrm{~min}$ to $290^{\circ} \mathrm{C}$ at $10^{\circ} \mathrm{C} / \mathrm{min}$ and then held for $5 \mathrm{~min}$. The chromatogram was processed with an HP-3395 integrator. A gas chromatograph/mass spectrometric (GC/MS) analysis was carried out using a Hewlett Packard HP-5890 GC/MS operated at $70 \mathrm{eV}$ in the split-less mode, using the same column and temperature conditions mentioned above.

Extraction method. A group of ten males or females was separately placed in a conical tube (handmade, $8 \mathrm{~mm}$ in diameter $\times 30 \mathrm{~mm}$ in height), and dipped in hexane $(4 \mu \mathrm{l})$ for 3 min. The hexane layer was then taken up with a micro syringe (10 $\mu$ l volume, Hamilton) and subjected to the GC/MS analysis.

For evaluating pheromonal activity, two females or males were extracted by dipping into hexane $(100 \mu \mathrm{l})$ for $3 \mathrm{~min}$. One microliter portion of the extract (corresponding to 0.02 
female or male equivalents) was assayed against males or females.

To determine the pheromone content in each sex, one female or one male was extracted at a time for $3 \mathrm{~min}$ in hexane ( $10 \mu \mathrm{l}$ for female and $5 \mu \mathrm{l}$ for male), containing tetradecane ( $2 \mathrm{ng} /$ $\mu \mathrm{l})$ as an internal standard. One microliter portion of each hexane extract corresponding to either 0.1 female or 0.2 male equivalents was analyzed by GC.

To determine the active compound(s), one hundred female mites were separated from the stock culture, and extracted by dipping in hexane $(100 \mu \mathrm{l})$ for $3 \mathrm{~min}$. The extract was, without concentration, subjected to a conventional silica gel column chromatography (Wakogel C-200, $800 \mathrm{mg}$ ), and the column was eluted with $5 \mathrm{ml}$ each of the following solvents: hexane, a mixture of ether in hexane $(10 \%, 20 \%$ and $50 \%)$, and ether. Then, each fraction ( $1 \mu \mathrm{l}$ portion, corresponding to 0.02 female equivalents) was subjected to bioassay. The remaining portions of each fraction were analyzed by GC/MS.

Biological assays. The bioassay was conducted in a small Petri dish $(8 \mathrm{~mm}$ in diameter $\times 5 \mathrm{~mm}$ in height), whose bottom surface was covered with a damp filter paper disc ( $8 \mathrm{~mm}$ in diameter). To the dish, ten males (or females) were introduced with a small amount of moistened dry yeast, and the dish was closed with a cover glass to prevent the mites from escaping. After 3-5 hours of conditioning, a female or a male was introduced at the center of the chamber to determine or to detect the presence of the pheromone. Similarly, a piece of filter paper $(2 \mathrm{~mm} \times 2 \mathrm{~mm})$ impregnated with the following candidate materials at the indicated doses was introduced: either female-, male-extract, column fractions or synthetic compounds (neral or geranial at $0.01,0.1,1,10$ and $100 \mathrm{ng} / \mu 1$ dose in hexane). A piece of filter paper impregnated with hexane was used as control. The number of mounting attempts by males was counted for 5 min under a binocular microscope. The assay was conducted at $23^{\circ} \mathrm{C}$ with repetition of 5-10 times in each case.

Preparation of neral and geranial. Neral (purity more than 97\%) and geranial (purity more than 99\%) were each prepared from nerol and geraniol as previously reported (Leal et al., 1989d).

Data analyses. The pheromone content of both sexes was analyzed by the Mann-Whitney $U$ test. For the bioassay, the results were processed to evaluate significant differences in the numbers of mounting attempts by the Mann-Whitney $U$ test or the Kruskal-Wallis test followed by the Dunn's multiple-comparison test.

\section{RESULTS}

Hexane extracts of both sexes commonly showed the following six peaks by GC/MS analyses with each quantitative difference; peak A $\left(t_{\mathrm{R}}=9.30 \mathrm{~min}\right)$, peak B $\left(t_{\mathrm{R}}=9.49 \mathrm{~min}\right)$, peak $\mathrm{C}\left(t_{\mathrm{R}}=9.90 \mathrm{~min}\right)$, peak $\mathrm{D}\left(t_{\mathrm{R}}=10.06 \mathrm{~min}\right)$, peak $\mathrm{E}\left(t_{\mathrm{R}}=10.28 \mathrm{~min}\right)$, peak $\mathrm{F}$ $\left(t_{\mathrm{R}}=11.02 \mathrm{~min}\right)$ (Fig. 1). Peak B was the major component in females, while it was the second major in males. The molecular and diagnostic ions of each peak are summarized in Table 1. Based on their mass spectra and GC retention times $\left(t_{\mathrm{R}}\right)$ together with those of authentic compounds, all the peaks (A-F) were identified to be nerol [3,7-dimethyl-(Z)-2,6octadienol] (Kuwahara and Suzuki, 1983), neral [3,7-dimethyl-(Z)-2,6-octadienal], geranial [3,7-dimethyl-(E)-2,6-octadienal] (Kuwahara et al., 1980a), $\alpha$-acaridial [(E)-2-(4-methyl-3pentenyl)-butenedial] (Leal et al., 1989c), tridecane (Howard et al., 1988) and $\beta$-acaridial 


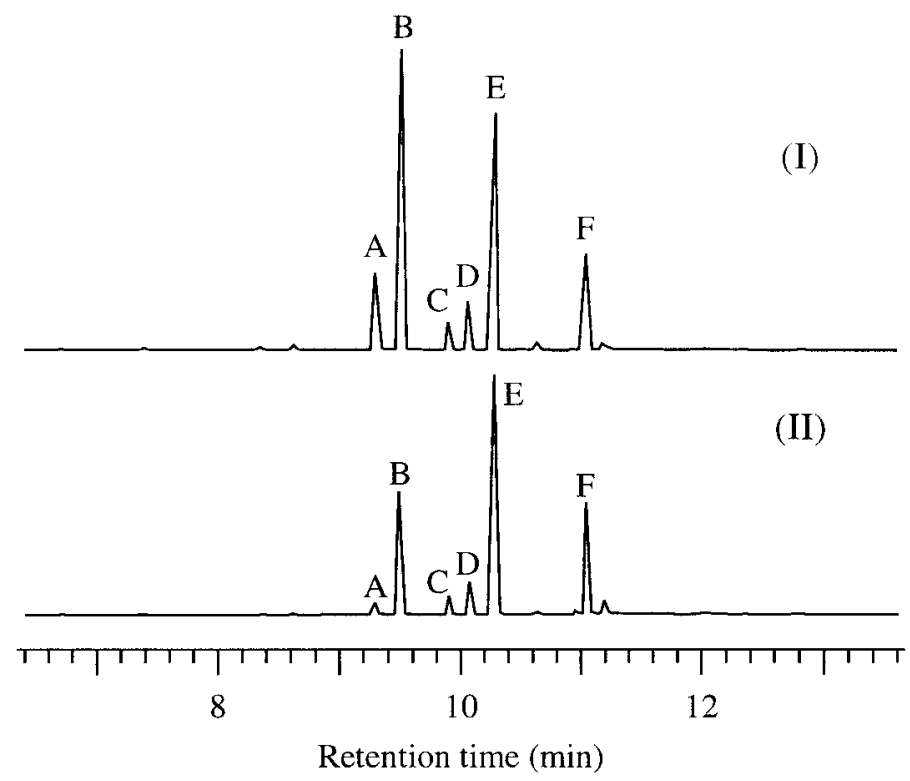

Fig. 1. Typical gas chromatograms of the hexane extracts from Histiogaster sp. (I) 10 female equivalents and (II) 10 male equivalents. Chromatograms were obtained with an HP-5 capillary column $(0.25 \mathrm{~mm} \times 30 \mathrm{~m}, 0.25 \mu \mathrm{m}$ in film thickness, programmed from $60^{\circ} \mathrm{C}$ for $2 \mathrm{~min}$ to $290^{\circ} \mathrm{C}$ at $10^{\circ} \mathrm{C} / \mathrm{min}$ and then held for $5 \mathrm{~min}$ ).

Table 1. GC/MS Data for Compounds Obtained from the Hexane Extract of Histiogaster sp. GC Retention Times, Molecular and Diagnostic Ions, and Relative Abundance

\begin{tabular}{|c|c|c|c|c|}
\hline \multirow{2}{*}{$\begin{array}{l}\text { Compound } \\
\text { (peak A-F) }\end{array}$} & \multirow{2}{*}{$\begin{array}{c}\mathrm{GC} \\
t_{\mathrm{R}}(\mathrm{min})\end{array}$} & \multicolumn{2}{|c|}{$\begin{array}{l}\text { Relative abundance } \\
\qquad(\%)\end{array}$} & \multirow{2}{*}{$\begin{array}{l}\text { Molecular and diagnostic ions } \\
\mathrm{m} / \mathrm{z} \text { (intensity \%) }\end{array}$} \\
\hline & & Female & Male & \\
\hline A: Nerol & 9.30 & 11.2 & 1.9 & $\begin{array}{l}41(68), 69(100), 84(20), 93(58), 121(23) \\
136(17), 154\left(\mathrm{M}^{+}, 5\right)\end{array}$ \\
\hline B: Neral & 9.49 & 37.9 & 22.1 & $\begin{array}{l}41(90), 69(100), 84(34), 94(46), 109(32), \\
119(20), 134(12), 137(8), 152\left(\mathrm{M}^{+}, 3\right)\end{array}$ \\
\hline C: Geranial & 9.90 & 3.8 & 1.9 & $\begin{array}{l}41(69), 69(100), 84(30), 94(22), 109(10) \\
123(9), 137(13), 152\left(\mathrm{M}^{+}, 9\right)\end{array}$ \\
\hline D: $\alpha$-Acaridial & 10.06 & 6.0 & 5.6 & $\begin{array}{l}41(100), 69(92), 95(15), 108(17), 119(15), \\
123(26), 133(25), 151(12), 166\left(\mathrm{M}^{+}, 10\right)\end{array}$ \\
\hline E: Tridecane & 10.28 & 29.4 & 47.7 & $\begin{array}{l}43(66), 57(100), 71(73), 85(49), 99(14), \\
113(9), 127(9), 141(7), 155(4), 184\left(\mathrm{M}^{+}, 24\right)\end{array}$ \\
\hline$F: \beta$-Acaridial & 11.02 & 11.7 & 20.8 & $\begin{array}{l}41(100), 55(48), 67(96), 81(54), 95(73), \\
108(44), 123(65), 133(68), 151(42), \\
166\left(\mathrm{M}^{+}, 25\right)\end{array}$ \\
\hline
\end{tabular}

[(E)-2-(4-methyl-3-pentenylidene)-butanedial] (Leal et al., 1989b), respectively.

When a female was introduced to an assay chamber containing conditioned males, the males started to mount the introduced female and/or other males. The average count of 
mounting attempts during the testing period was observed to be $10.3 \pm 0.4(n=10)$. Although the same behavior was observable by a male introduction to the chamber, the count was significantly less frequent, $6.5 \pm 0.5(n=10)$ on average. There was a significant difference between these two cases (Mann-Whitney $U$ test, $p<0.01$ ), and therefore, the males could discriminate the females from the males.

Upon exposure of a piece of filter paper impregnated with 0.02 equivalent of female or male extract, the tested males were aroused sexually and mounting behavior was also observable. The resulting mounting frequency was $8.1 \pm 0.6(n=10)$ on average for the female extract, while it was $5.8 \pm 0.3(n=10)$ on average for the male extract and $3.5 \pm 0.2$ $(n=10)$ for the hexane impregnated control (Fig. 2). Significant differences were demonstrated between mite extracts and control (Kruskal-Wallis test followed by the Dunn's multiple-comparison test, $p<0.01$ for the female extract and $p<0.05$ for the male extract). The presence of the female sex pheromone was, therefore, confirmed not only by a female alone but also by the hexane extract. There was no significant difference observed between the extracts from females and males (Kruskal-Wallis test followed by the Dunn's multiplecomparison test, $p>0.05$ ), although the female extract triggered more frequent mounting attempts than the male extract.

The $10 \%$ ether in hexane fraction obtained by a silica gel column using the hexane extract from 100 females was concluded to be active by bioassay (Fig. 3), and the fraction consisted of a mixture of neral and geranial by GC/MS analyses (Fig. 3). Either geranial or neral might, therefore, be the female sex pheromone.

The dose-response relationship of synthetic neral indicated a convex curve with the maximum activities at 0.1 and $1 \mathrm{ng}$-dose within the range examined from $0.01 \mathrm{ng}$ to $100 \mathrm{ng}$

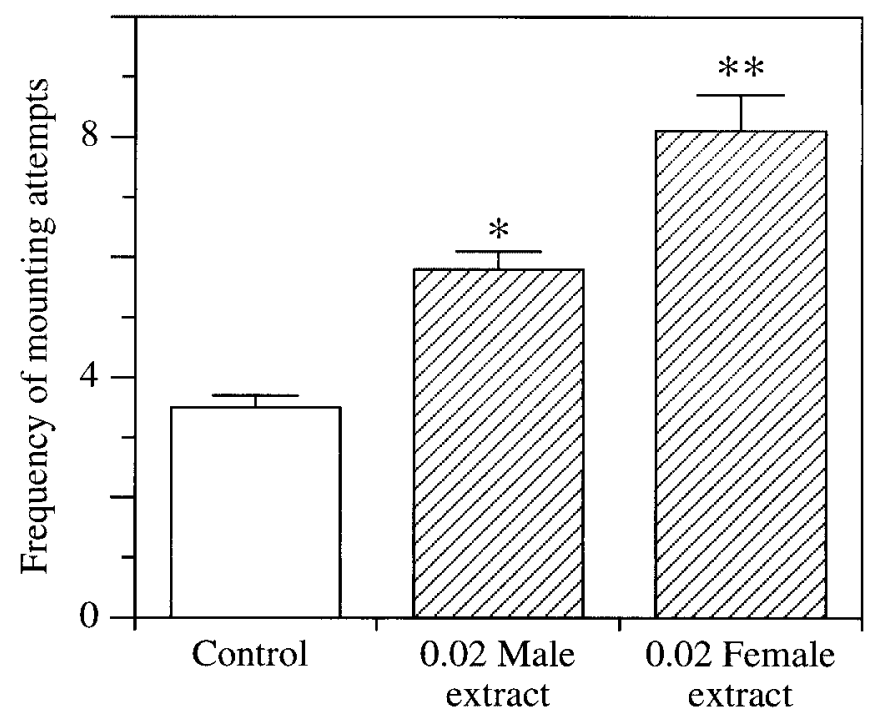

Fig. 2. Sex pheromone activity of the hexane extracts from Histiogaster sp. 0.02 female equivalents and 0.02 male equivalents $\left({ }^{*} p<0.05\right.$, $*^{*} p<0.01$, Kruskal-Wallis test followed by Dunn's multiple-comparison test, each $n=10$ ). 


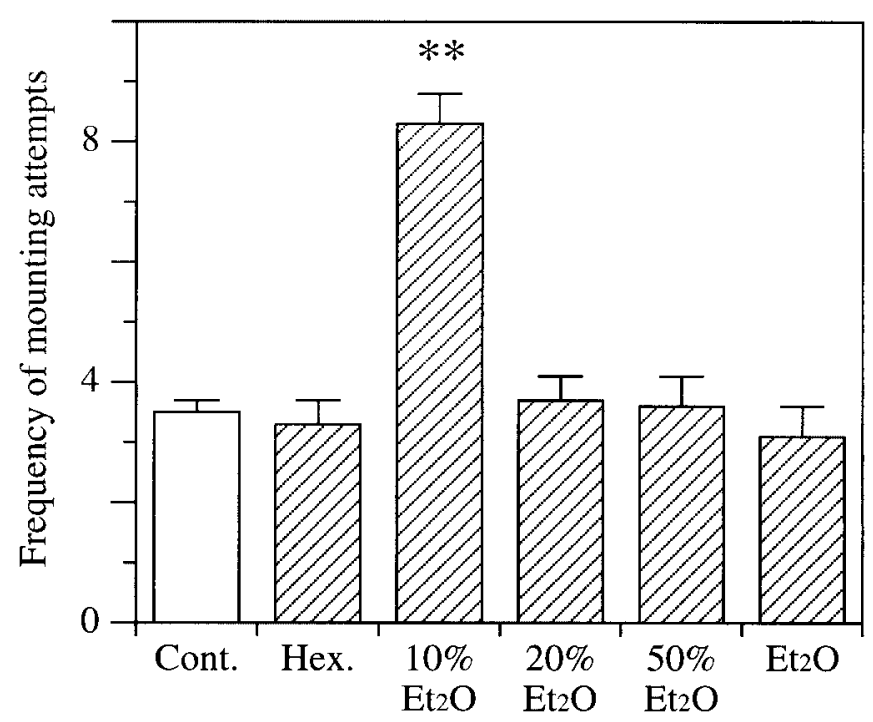

Fig. 3. Purification procedure to the hexane extract of mites and the sex pheromone activity of each fraction at 0.02 female equivalents $\left({ }^{* *} p<0.01\right.$, Kruskal-Wallis test followed by Dunn's multiple-comparison test, each $n=10$ ).

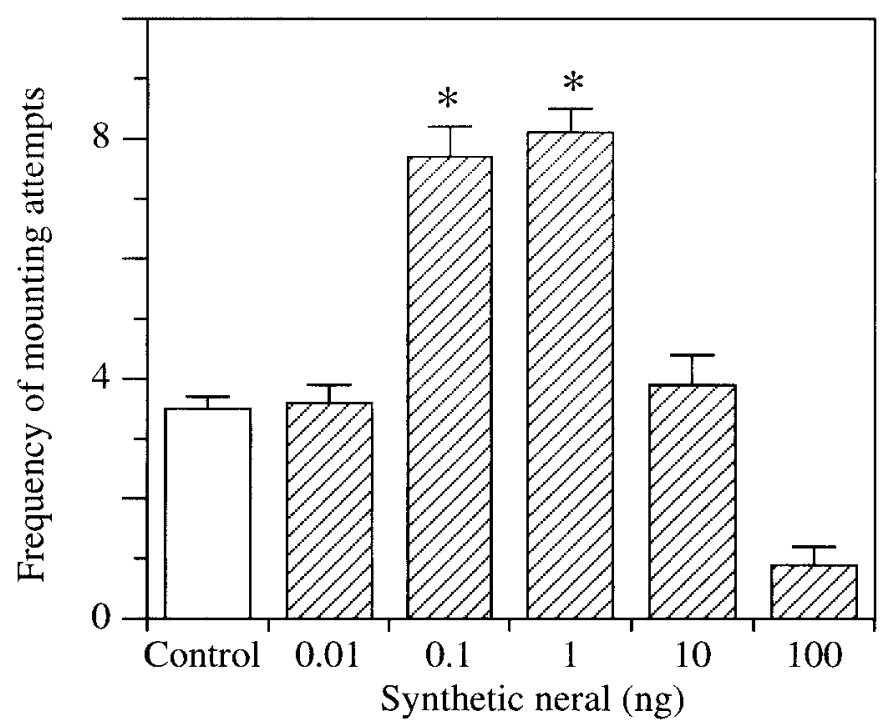

Fig. 4. Sex pheromone activity of synthetic neral $\left({ }^{*} p<0.05\right.$, Kruskal-Wallis test followed by Dunn's multiple-comparison test, each $n=10)$.

(Fig. 4). Significant differences were demonstrated between control and either 0.1 or $1 \mathrm{ng}$ dose (Kruskal-Wallis test followed by the Dunn's multiple-comparison test, $p<0.05$ ). On the other hand, synthetic geranial did not sexually stimulate males: the resulting mounting frequencies were $3.2 \pm 0.4,3.2 \pm 0.4,3.8 \pm 0.4,0.8 \pm 0.6,0.0 \pm 0.0$ (each case, $n=5$ ) for $0.01,0.1$, 
1, 10 and $100 \mathrm{ng}$ doses, respectively. As a result, neral was concluded to be the female sex pheromone. The pheromone activitiy was lost at a $10 \mathrm{ng}$ dose of neral, and males escaped from the test filter paper at $100 \mathrm{ng}$ dose. The same escaping behavior was observed when $10-100 \mathrm{ng}$ of geranial was introduced.

The pheromone neral was contained as the major component in females at $29.4 \pm 8.9 \mathrm{ng}$ $(n=5)$ on average, whereas it was the second major in males at 5.7 $\pm 1.9 \mathrm{ng}(n=5)$ among six components detected by GLC (Fig. 1 and/or Table 1). The pheromone content ratio of females to males is ca. 5.2/1. This represents a significant difference between sexes (MannWhitney $U$ test, $p<0.05)$.

\section{DISCUSSION}

Neral (active at $0.1-1 \mathrm{ng}$ doses) was identified to be the female sex pheromone of the mite Histiogaster sp., although the compound was present not only in females $(29.4 \pm 8.9 \mathrm{ng})$ but also in males $(5.7 \pm 1.9 \mathrm{ng}$ ), as in the cases of other astigmatid mites (Mori and Kuwahara, 2000). This is consistent with the fact that both extracts from each sex demonstrated the activity at 0.02 mite equivalents, which corresponded to ca. $0.6 \mathrm{ng}$ and ca. $0.1 \mathrm{ng}$ of neral. The same mounting behavior was observed when a male or a female was introduced to the assay chamber containing conditioned males, although a higher frequency was recorded upon a female introduction (10.3 \pm 0.4$)$ than a male introduction (6.5 \pm 0.5$)$. This implies that a male could distinguish females from males for mounting and mating. In fact, mountings (and matings) were exclusively observable between female and male combinations in the stock culture, and homosexual mounting took place only in the assay chamber. It was also often noticeable in the stock culture that a female was carrying more than two males competing with each other on her abdomen. This male preference toward females was explainable by the content ratio of the pheromone (5.2/1). Species with a ratio of more than 3.4/1 are classified as the ones whose males can discriminate sexes and select a mate among the genus Sancassania (=Caloglyphus) (Mori and Kuwahara, 2000).

The sex pheromone activity of synthetic neral was lost at a $10 \mathrm{ng}$ dose, whereas escaping behavior was observed at a $100 \mathrm{ng}$ dose not only among males but also females. This $100 \mathrm{ng}$ of neral corresponds to 3.4 female equivalents, and implies the possibility of an alarm pheromone function in the species. Recently, the sex pheromone of S. polyphyllae, $\beta$-acaridial has also been found to function as an aggregation pheromone (Shimizu et al., 2001), and the alarm pheromone neral in Schwiebea elongata has also been found to function as the attractant (Nishimura et al., 2002). Further study will be needed to conclude the presence of the alarm pheromone in the present species, because mites near to disturbed or squashed ones did not unambiguously escape in the stock culture, and squashed mites were often eaten by ones nearby. There is, however, a small possibility that mites may start escaping when a large number of mites are squashed at the same time in the natural environment.

On the other hand, geranial, the geometrical isomer of neral at the 2- $C$ position, exhibited no sexual activity within the same dose range examined (0.01-100 ng) as neral. The results suggested the male's ability to discriminate the geometrical isomer. Upon exposure to a 10and 100-ng dose against both sexes unexpectedly displayed the escaping behavior. This fact, however, may not be important as a biological function, because geranial was the most 
minor component in the extract from both sexes.

Neral is one of the most widely distributed components among astigmatid mites, and has been detected in 31 species among the 52 species investigated (Kuwahara, 1999). Five species use the compound as their alarm pheromone: Carpoglyphus lactis, Lardoglyphus konoi (Kuwahara et al., 1980b), Suidasia medanensis (Leal et al., 1989d), Glycyphagus domesticus (Kuwahara et al., 1991), Schwiebea elongata (Kuwahara et al., 2001). However, this is the first example identifying the function of neral as the female sex pheromone. It is also the first identification of the female sex pheromone among species belonging to the genus Histiogaster.

\section{Acknowledgement}

This study was partly supported by research funding from Daily Foods Corporation (Tokyo).

\section{REFERENCES}

Davis, R. and P. E. Hunter (1963): Biological studies of a Histiogaster mite (Acarina: Acaridae) associated with pine reproduction weevils. Ann. Entomol. Soc. Am., 56: 682-687.

Griffiths, D. A. (1963): A new species of Histiogaster belonging to the family Acaridae, Owing and Nesbit 1942 (Acarina). Acarologia, 5: 61-70.

Hajek, A. E. and D. L. Dahlsten (1985): Insect and mite associates of scolytus Scolytus Multistriatus (Coleoptera: Scolytidae) in California. Can. Entomol., 117: 409-421.

Howard, W. H., Y. Kuwahara, H. Suzuki and T. Suzuki (1988): Pheromone study on acarid mites. XII. Characterization of the hydrocarbons and external gland morphology of the opisthonotal glands of six species of mites (Acari: Astigmata). Appl. Entomol. Zool., 23: 58-66.

Jacot, A. P. (1936): Three possible mite vectors of the Dutch elm disease. Ann. Entomol. Soc. Am., 29: 627-635.

Kinn, D. N. (1987): Incidence of pinewood nematode dauer larvae and phoretic mites associated with long-horned beetles in central Lousiana. Can. J. For. Res., 17: 187-190.

Kuwahara, Y. (1999): Chemical ecology of astigmatid mites. In Environmental Entomology (T. Hidaka, Y. Matsumoto, K. Honda, H. Honda and S. Tatsuki ed.). University of Tokyo Press, Tokyo, pp. 380-393. (in Japanese)

Kuwahara, Y., T. Ibi, Y. Nakatani, A. Ryono, N. Mori, T. Sakata, K. Okabe, K. Tagami and K. Kurosa (2001): Chemical ecology of astigmatid mites LIX. Neral, the alarm pheromone of Schwiewea elongata (Banks) (Acari: Acaridae). J. Acarol. Soc. Jpn., 10: 19-25.

Kuwahara, Y., T. Koshii, M. Okamoto, K. Matsumoto and T. Suzuki (1991): Chemical ecology on astigmatid mites XXX. Neral as the alarm pheromone of Glycyphagus domesticus (De Geer) (Acarina: Glycyphagidae). Jap. J. Sanit. Zool., 42: 29-32.

Kuwahara, Y., H. Fukami, S. Ishii, K. Matsumoto and Y. Wada (1980a): Pheromone study on acarid mites III. Citral: Isolation and identification from four species of acarid mites, and its possible role. Jap. J. Sanit. Zool., 31: $49-52$.

Kuwahara, Y., K. Matsumoto and Y. Wada (1980b): Pheromone study on acarid mites IV. Citral: Composition and function as an alarm pheromone and its secretory gland in four species of acarid mites. Jap. J. Sanit. Zool., 31: $73-80$.

Kuwahara, Y., M. Sato, T. Koshii and T. Suzuki (1992): Chemical ecology of astigmatid mites XXXII. 2-Hydroxy6-methyl-benzaldehyde, the sex pheromone of the brown-legged grain mite Aleuroglyphus ovatus (Troupeau) (Acarina: Acaridae). Appl. Entomol. Zool., 27: 253-260.

Kuwahara, Y. and H. Suzuki (1983): Pheromone study on acarid mites XI. Function of mite body as geometrical isomerization and reduction of citral (the alarm pheromone). Appl. Entomol. Zool., 18: 30-39.

Leal, W. S., Y. Kuwahara, Y. Nakano, H. Nakao and T. Suzuki (1989c): 2(E)-(4-Methyl-3-pentenyl)-butenedial, $\alpha$ acaridial, a novel monoterpene from the acarid mite Tyrophagus perniciosus (Acarina, Acaridae). Agric. Biol. 
Chem., 53: 1193-1196.

Leal, W. S., Y. Kuwahara and T. Suzuki (1989b): 2(E)-(4-Methyl-3-pentenylidene)-butanedial, $\beta$-acaridial: A new type of monoterpene from the mold mite Tyrophagus putrescentiae (Acarina, Acaridae). Agric. Biol. Chem., 53: $875-878$.

Leal, W. S., Y. Kuwahara, T. Suzuki and K. Kurosa (1989a): $\beta$-Acaridial, the sex pheromone of the acarid mite Caloglyphus polyphyllae. Pheromone study of acarid mites XXI. Naturwissenschaften, 76: 332-333.

Leal, W. S., Y. Kuwahara, T. Suzuki and K. Kurosa (1989d): The alarm pheromone of the mite Suidasia medanensis Oudemans, 1924 (Acariformes, Suidasiidae). Agric. Biol. Chem., 53: 2703-2709.

Levinson, A. R., H. Z. Levinson and U. Oelker (1989): Two sex pheromones mediate courtship and mating in the flour mite. Naturwissenschaften, 76: 176-177.

Mori, N. and Y. Kuwahara (2000): Comparative studies of the ability of males to discriminate between sexes in Caloglyphus spp. J. Chem. Ecol., 26: 1299-1309.

Mori, N., Y. Kuwahara, K. Kurosa, R. Nishida and T. Fukushima (1995): Chemical ecology of astigmatid mites XLI. Undecane: The sex pheromone of the acarid mite Caloglyphus rodriguezi Samsinák (Acarina: Acaridae). Appl. Entomol. Zool., 30: 415-423.

Mori, N., Y. Kuwahara and K. Kurosa (1996): Chemical ecology of astigmatid mites XLV. (2R,3R)-Epoxyneral: Sex pheromone of the acarid mite Caloglyphus sp. (Acarina: Acaridae). Bioorg. Med. Chem., 4: 289-295.

Mori, N., Y. Kuwahara and K. Kurosa (1998): Rosefuran: The sex pheromone of an acarid mite Caloglyphus sp. J. Chem. Ecol., 24: 1771-1779.

Nesbitt, H. H. J. (1945): A revision of the family Acaridae (Tyroglyphidae), order Acari, based on comparative morphological studies. I. Historical, morphological, and general taxonomic studies. Can. J. Res. Sect. D. Zool. Sci., 23: 139-188.

Nishimura, K., N. Shimizu, N. Mori and Y. Kuwahara (2002): Chemical ecology of astigmatid mite LXIV. The alarm pheromone neral functions as attractant in Schwiebea elongata (Banks) (Acari: Acaridae). Appl. Entomol. Zool., 37: 13-18.

Okabe, K. (1993a): Population growth and dispersal behavior of Histiogaster sp. (Acari: Acaridae) on several economically important fungi. Appl. Entomol. Zool., 28: 11-18.

Okabe, K. (1993b): Developmental period and fecundity of Histiogaster sp. (Acari: Acaridae) on three fungi. Appl. Entomol. Zool., 28: 479-487.

Okabe, K. (1994): Inhibition of egg hatching of Histiogaster sp. (Acari: Acaridae) by shiitake mushrooms (Lentinus edodes). J. Acarol. Soc. Jpn., 3: 1-5.

Okabe, K. (1996): Inhibition of development of Histiogaster sp. (Acari: Acaridae) by shiitake mushrooms Lentinus edodes. Appl. Entomol. Zool., 31: 211-216.

Okabe, K. (1999): Vectoring of Hypocrea nigricans (Hypocreales: Hypocreaceae) by three fungivorous mite species (Acari: Acaridae). Exp. Appl. Acarol., 23: 653-658.

Ryono, A., N. Mori, K. Okabe and Y. Kuwahara (2001): Chemical ecology of astigmatid mites LVIII. 2-Hydroxy-6methylbenzaldehyde: Female sex pheromone of Cosmoglyphus huguesi Samsinák (Acari: Acaridae). Appl. Entomol. Zool., 36: 77-81.

Sato, M., Y. Kuwahara, S. Matsuyama, T. Suzuki, M. Okamoto and K. Matsumoto (1993): Male and female sex pheromones produced by Acarus immobilis Griffiths (Acaridae: Acarina). Chemical ecology of astigmatid mites XXXIV. Naturwissenschaften, 80: 34-36.

Shimizu, N., N. Mori and Y. Kuwahara (2001): Aggregation pheromone activity of the female sex pheromone, $\beta$ acaridial, in Caloglyphus polyphyllae (Acari: Acaridae). Biosci. Biotechnol. Biochem., 65: 1724-1728.

Woodring, J. P. (1963): New species of Histiostoma (Anoetidae) and Histiogaster (Acaridae) with observations on their biology (Acari). Proc. Lousiana Acad. Sci., 26: 49-57.

Woodring, J. P. (1966): North American Tyroglyphidae (Acari): III. The genus Histiogaster, with description of four new species. Proc. Lousiana Acad. Sci., 29: 113-136. 
摘要

ネラール：コナダニ科 Histiogaster sp. 雌性フェロモンの同定 平岡弘之・森 直樹・ 西田律夫・桑原保正 (京大院農) ・岡部貴美子（森林総研）

ネラール（3,7- ジメチル -(Z)-2,6- オクタジェナール）をHistiogaster 属未同定種の此倠の性 フェロモンとして同定した。このダニは椎茸栽培時に発生した病原系状菌 Trichoderma harzianum の菌そうから採集された種である．ネラールは雄ダニを性的に興奮させ、定量す ると雌には $29.4 \pm 8.9 \mathrm{ng}$ 、雄には $5.7 \pm 1.9 \mathrm{ng}$ 含まれていた。 他の無気門亜目ダニと同様にフェ ロモンは雄ダニにも存在したが、行動観察から雄ダニは雌ダニを識別できると判断した。合 成化合物は 0.1-1 ng で活性を示した. 一方幾何異性体のゲラニアール (3,7- ジメチル $-(E)-2,6-$ オクタジエナール）に活性は認められず、雄はネラールとゲラニアールを区別できることが 判明した.ネラールを $100 \mathrm{ng}$ 、ゲラニアールを10-100 ng 投与するとダニは忌避行動を示した. 